Research Article

\title{
Silver Nanorods Layer Based on Polyvinyl Alcohol on Glass Substrates by Dip-Coating Method
}

\author{
Junaidi $^{1, a}$, Agus Riyanto ${ }^{1, b}$, Kuwat Triyana ${ }^{2, c}$, and Khairurrijal ${ }^{3, d}$ \\ ${ }^{1}$ Department of Physics, Faculty of Mathematics and Natural Sciences, Universitas Lampung \\ Jalan Prof. Dr. Sumantri Brojonegoro No. 1, Bandar Lampung 35144, Indonesia \\ ${ }^{2}$ Department of Physics, Faculty of Mathematics and Natural Sciences, Universitas Gadjah Mada \\ Sekip Utara Bulaksumur, Yogyakarta 55281, Indonesia \\ ${ }^{3}$ Department of Physics, Faculty of Mathematics and Natural Sciences, Institut Teknologi Bandung \\ Jalan Tamansari 64, Bandung 40132, Indonesia \\ e-mail: ${ }^{\mathrm{a}}$ junaidi.1982@.fmipa.unila.ac.id, ${ }^{\mathrm{b}}$ agus.riyanto@fmipa.unila.ac.id, ${ }^{\mathrm{c}}$ triyana@ugm.ac.id, \\ and ${ }^{\mathrm{d}}$ krijal@fi.itb.ac.id
}

\begin{abstract}
This research reports the investigation of the performance of a thin layer based on silver nanorods using the dip-coating method. The synthesis was conducted by polyol method at an oil bath temperature of $140{ }^{\circ} \mathrm{C}$. In the synthesis of silver nanorods, materials used were silver nitrate ( $\left.\mathrm{AgNO}_{3}\right)$ as the main raw material, ethylene glycol (EG) as the solvent, and a small amount of sodium chloride (NaCl) as a mediated-agent (precursor). Polyvinyl alcohol (PVA) used as a capping agent and stabilizer in this process. Diameter and length of silver nanorods were $800 \mathrm{~nm}$ and $15 \mu \mathrm{m}$, respectively. Furthermore, the silver nanorods suspension was deposition onto a glass substrate with a variety of dipping cycles. The result showed the thickness of the thin layer is linear with a number of dipping cycles. Electrical and optical properties of thin layer show that sheet resistance about of $30 \Omega \mathrm{sq}^{-1}$ by transmittance above of $80 \%$. The silver nanorods thin film can be used as a conductive and transparent electrode for various optoelectronic applications.
\end{abstract}

Keywords: silver nanorods, transparent electrode, optical properties, sheet resistance, dip-coating

\section{Lapisan Tipis Silver Nanorods Berbasis Polivinil Alkohol pada Subtrat Kaca dengan Metode Dip Coating}

\begin{abstract}
Abstrak
Pada penelitian ini, kami telah menyelidiki kinerja dari lapisan tipis berbasis silver nanorods menggunakan metode dip-coating. Sintesis dilakukan dengan metode poliol dalam media oil bath pada suhu $140^{\circ} \mathrm{C}$. Dalam sintesis silver nanorods, bahan yang digunakan adalah perak nitrat ( $\left.\mathrm{AgNO}_{3}\right)$ sebagai bahan baku utama, etilen glikol (EG) sebagai pelarut, dan sedikit natrium klorida ( $\mathrm{NaCl}$ ) sebagai agen mediasi (precursor). Polivinil alkohol (PVA) digunakan sebagai capping agent dan penstabil dalam proses ini. Diameter dan panjang silver nanorods diperoleh masing-masing $800 \mathrm{~nm}$ dan $15 \mu \mathrm{m}$. Selanjutnya, suspensi silver nanorods dilapiskan di atas substrat kaca dengan variasi jumlah celupan. Hasil penelitian menunjukkan bahwa ketebalan lapisan tipis adalah linier dengan jumlah pencelupan.
\end{abstract}

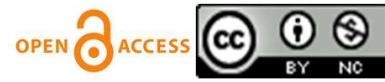


Jurnal Penelitian Fisika dan Aplikasinya (JPFA), 2019; 9(1): 1-9

Sifat listrik dan optik dari lapisan tipis menunjukkan bahwa hambatan dari lembaran diperoleh sekitar $30 \Omega s q^{-1}$ dengan transmitansi di atas $80 \%$. Film tipis silver nanorods dapat digunakan sebagai elektroda konduktif dan transparan untuk berbagai aplikasi piranti optoelektronika.

Kata Kunci: silver nanorods, elektroda transparan, sifat optik, resistansi lembar, dip-coating

PACS: 78.67.Uh, 78.67.Qa, 81.07.Gf, 81.15.Rs, 07.05.Dz

(C) 2019 Jurnal Penelitian Fisika dan Aplikasinya (JPFA). This work is licensed under CC BY-NC 4.0

Article History: Received: September 17, 2018

Revised (Round 1): February 4, 2019

Accepted: June 27, 2019
Decided to resubmit (Round 1): January 3, 2019

Approved with minor revision: May 13, 2019

Published: June 30, 2019

How to Cite: Junaidi, Riyanto A, Triyana K, and Khairurrijal. Silver Nanorods Layer Based on Polyvinyl Alcohol on Glass Substrates by Dip-Coating Method. Jurnal Penelitian Fisika dan Aplikasinya (JPFA). 2019; 9(1): 1-9. DOI: https://doi.org/10.26740/jpfa.v9n1.p1-9.

\section{INTRODUCTION}

The number of electronic devices for a display and touch screens has increased significantly in the last decade [1]. The transparent electrode can be used for various electronic devices, such as organic solar cells, displays, touch screens, and transparent heaters. Inorganic solar cells, the transparent electrode is used for anode or cathode to produce a charge carrier. It is believed that the transparent electrodes have several advantages, i.e. flexible substrate, easy to fabrication, low cost, and lightweight. The widest materials used for the transparent electrodes are metal oxides of indium tin oxide (ITO). ITO is a highly transparent electrode with the transmittance $(T=80-95 \%)$ and low sheet resistance $\left(R s=10-1000 \Omega \mathrm{sq}^{-1}\right)$ [2-3].

ITO, however, cannot cover all qualifications thanthe expected as a transparent electrode. ITO has some weaknessessuch as (a) ITO by nature has the ceramics properties (not flexible), easy to crack because of the low strain and have a rapid decline in the conductivity, (b) indium is a rare material, so it is very expensive, (c) the process to make ITO is very expensive as it requires high temperature and vacuum to control the thickness, (d) ITO should kept in a special place in order to avoid any damages of the base layer organic devices, and (e) ITO has high refractive index which is not suitable for display applications because can be to reflect light and reduce the brightness of the screen [4-5].

Several researches have been conducted to solve problems associated with the transparent electrode of ITO. For example, ITO made a flexible electrode by drop-coated onto flexible substrates such as polyethylene terephthalate (PET). However, it does not only increase the production costs but also reduces the optical and electrical performance of an electrode. Therefore, many researchers have tried to find the alternative materials to replace ITO in the last decade. The materials used to substitute ITO include carbon nanotubes (CNTs), graphene, and metal nanorods or nanowires. The alternative materials have also been generated that it can apply as a substitute for ITO transparent electrode [5-8].

One of the main focuses of the research is the manufacture of a transparent electrode by using silver nanorods (AgNRs) or silver nanowires (AgNWs) [9]. Silver by nature is high electrical and thermal conductivity, transparency and stability [10-13]. The manufacture of a transparent electrode based on AgNWs and AgNRs was performed using Meyer-rod coating, spin coating, spray 
Jurnal Penelitian Fisika dan Aplikasinya (JPFA), 2019; 9(1): 1-9

coating, dip-coating, brush-painting, electrospinning, and roll-to-roll process. The deposition process was carried out onto a transparent glass substrate, quartz glass, PET, and ITO. In the manufacture of a transparent electrode, the main attention focused on some important factors, such as conductivity $(\sigma)$, resistance $\left(R_{S}\right)$, the transmittance $(T)$, and haze. Transparent electrode developed using silver nanorods or nanowires have sheet resistance of $\sim 50 \Omega \mathrm{sq}^{-1}$, transmittance above of $75 \%$, and the haze below of $5 \%$ [14-21].

This study develops a transparent electrode based on silver nanorods. The synthesis of silver nanorods used polyvinyl alcohol (PVA) as a capping agent and stabilizer. PVA is a non-toxicity polymer, have good mechanical strength, electrochemical stability, low membrane permeability, and high crystallinity. Deposition process was carried out by assessing the effect of variations of dipping cycles to the optical and electrical conductivity of AgNRs thin layer. Furthermore, AgNRs thin layer characterized using a current-voltage (I-V meter), a voltageresistance meter data acquisition system (DAS MA-16), a digital multimeter, a UV-vis spectrometer, and scanning electron microscope (SEM).

\section{METHOD}

Materials and preparation: Silver nitrate (AgNO 3 , Merck), polyvinyl alcohol (PVA Mw. 31000-50000 g/mol, Sigma-Aldrich), sodium chloride ( $\mathrm{NaCl}, 98 \%$, Merck), ethylene glycol (EG, $99 \%$, Merck), ethanol (EtOH, $98 \%$, Merck), deionized water, and glass substrate. Silver nanorods with an average diameter of approximately $800 \mathrm{~nm}$ and length of 10 to 20 $\mu \mathrm{m}$ were synthesized by the reduction of silver nitrate in the present of polyvinyl alcohol in ethylene glycol by polyol method.

The amount of ethylene glycol was heated at $140{ }^{\circ} \mathrm{C}$ and $700 \mathrm{rpm}$ for $10 \mathrm{~min}$. Furthermore, solution of $\mathrm{AgNO}_{3} / \mathrm{EG}$,
$\mathrm{NaCl} / \mathrm{EG}$, and PVA/EG (0.5 M, $10 \mathrm{mM}, 2 \mathrm{M})$ was injected for $0.5 \mathrm{cc} / \mathrm{min}$. After the mixture for 2 hours, the resulting AgNRs suspension was separated and washed with ethanol by centrifugation at the rate of $6000 \mathrm{rpm}$ for three times to remove supernatant.

Thin layer was fabricated using AgNRs suspensions by dip-coating method onto the glass substrate $10 \times 25 \mathrm{~mm}^{2}$. Glass substrates were cleaned with deionized water and ethanol for $30 \mathrm{~min}$ in an ultrasonic bath. Finally, the thin layer was dried in an oven at $200{ }^{\circ} \mathrm{C}$ for $10 \mathrm{~min}$ to remove the solvent.

Characterization of transparent electrodes: The electrical and optical properties of the transparent electrode were measured using a current-voltage (I-V meter, ELKAHFI-100), a voltage-resistance meter data acquisition system (V-R meter, DAQ MA-16), a digital multimeter (DT-850L), and a UV-vis spectrometer (Shimadzu, UV-1700). The hybrid electrodes on the glass substrate were observed using a field-emission scanning electron microscope (FE-SEM) (JEOL, JSM-6510LA) by accelerating the voltage of $10 \mathrm{kV}$.

\section{III.RESULTS AND DISCUSSION}

A transparent conductive electrode was produced using a simple dip-coating method. The silver nanorods deposition process was carried out onto a glass substrate $10 \times 25 \mathrm{~mm}^{2}$. The optical absorbance of AgNRs suspension was characterized using a UV-vis spectrophotometer in the wavelength range of 300 to $700 \mathrm{~nm}$ as shown in Figure 1 .

The optical absorbance of AgNRs suspension obtained two absorbance peaks, namely at $380 \mathrm{~nm}$ and $390 \mathrm{~nm}$. All peaks indicate that the optimum AgNRs was formed from the synthesis process. According to some references, the peak of the absorption spectrum of AgNRs is ranged from 350 to $390 \mathrm{~nm}[24,25]$. 


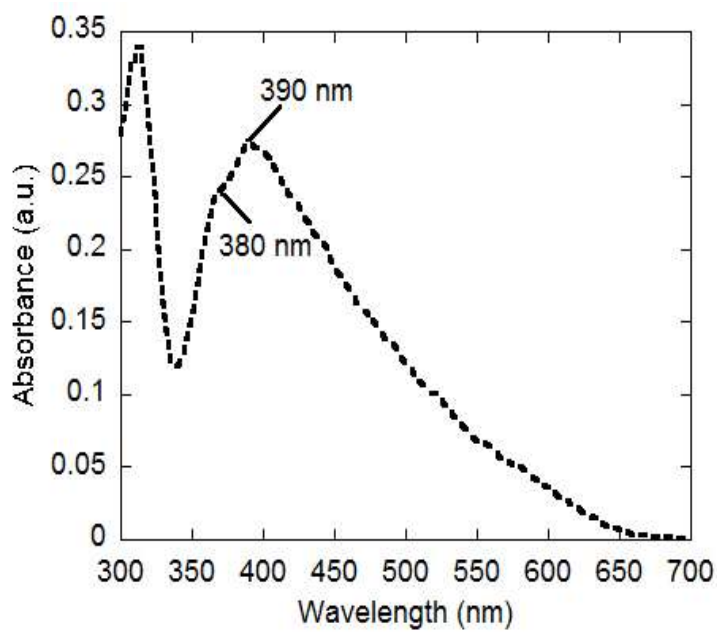

Figure 1. UV-vis Spectra of AgNRs Suspension

The dip-coating method is a simple method for deposition materials by dipping a substrate into AgNRs solution. The coating process of the substrate was repeated with variations in the number of dipping cycles. When the substrate was dipped and withdrawn from the AgNRs solution, then the number of AgNRs would be attached to the substrate with a solvent. To evaporate and eliminate the solvent, then the glass substrate was heated at a temperature of $200{ }^{\circ} \mathrm{C}$ for 10 minutes for each cycle. The thickness of the thin layer was highly dependent on the number of dipping cycles, the speed of cycles dipping, solvent vapor pressure, and the concentration of the AgNRs solution [19]. Diagram process for making the AgNRs layer by the dip-coating method can be illustrated in Figure 2(a-c).

Figure 2(d) shows the number of dipping cycles of AgNRs suspension deposition which was linear with the sheet resistance and inverse with the value of optical transmittance. When the coating process was carried out, the number of dipping cycles would continue to expand the number of AgNRs attached to the substrate. This results in the value of the optical transparency of the substrate would decrease according to the thickness of the AgNRs layer. The number of dipping cycles can increase the value of the sheet resistance of the AgNRs layer. The absence of built-up effect due to repeated dyeing process shows the AgNRs was coated strongly on the substrate [26].
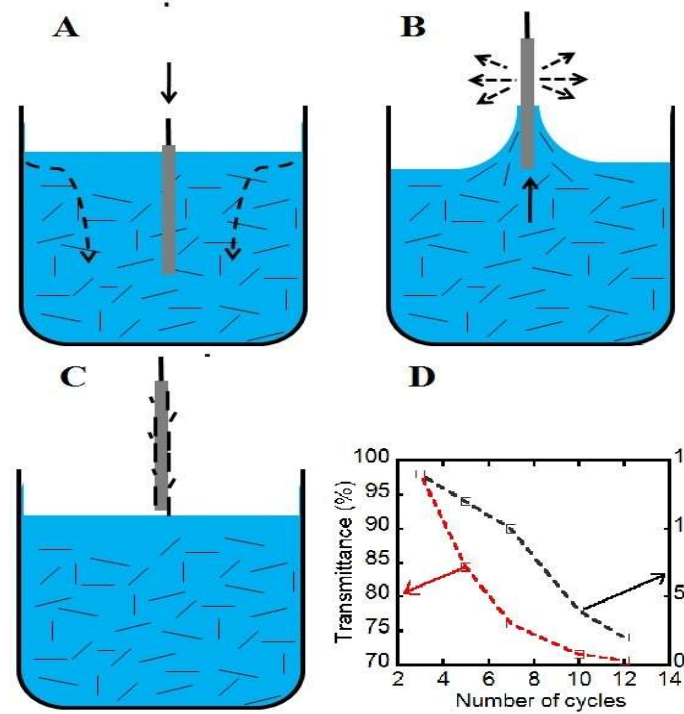

D

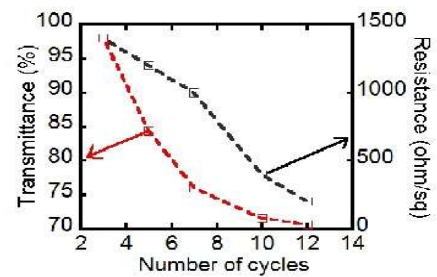

Figure 2(a-c). Illustration of the Workflow of DipCoating and (d) the Resulting Plot of the

Transmittance and Resistance by the Number of Cycles

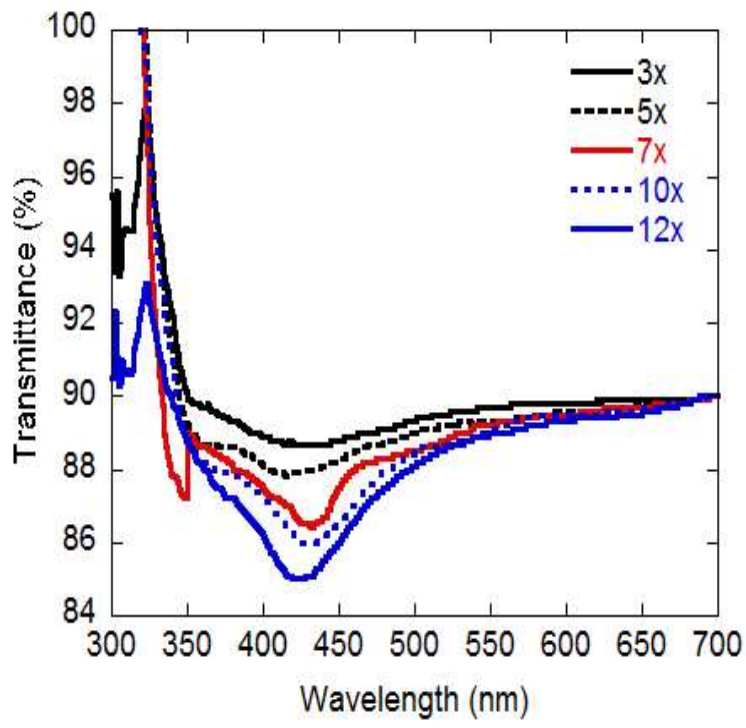

Figure 3. UV-vis Spectrometer of AgNRs Layer

Optical transmittance of the AgNRs layer is shown in Figure 3 and Figure 4(a) the optical transmittance was measured using a UV-vis spectrophotometer and DAS MA-16 with a glass substrate as a reference. The DAS MA-16 is an instrument that can measure the optical and electrical properties of a thin layer. 
The measurement process of optical transmittance from the AgNRs layer was conducted in a closed chamber in the absence of light (dark conditions). A laser diode beam with a wavelength of 630 to $680 \mathrm{~nm}$ was fired perpendicular to the surface of the glass substrate without and with coated of AgNRs suspension. The measurement process was performed for 30 seconds for each sample. The optical transmittance rate was obtained by comparing the voltage value of the sample read on the photodiode and AgNRs layer with the blank glass substrate.

The optical transmittance of the AgNRs layer decreased with the number of dipping cycles. The optical transmittance of the AgNRs layer is as shown in Table 1. The optical transmittance of the AgNRs layer with a UV-vis spectrophotometer and DAS MA-16 shows the same value about of $80-90 \%$. Optical transmittance is an important factor in determining the level of transparency and conductivity of a transparent electrode. The high value of transmittance in a wavelength range of $400-700 \mathrm{~nm}$ identifies that the AgNRs layer is excellent to bes used as a transparent electrode of organic solar cells $[27,28]$.

Sheet resistance $\left(R_{S}\right)$ of the AgNRs layer was measured by using a current-voltage (IV meters) at a voltage range of 0 to $130 \mathrm{mV}$ and a digital multimeter as shown at Figure 4(b). The relationship between the number of dipping cycles, optical transmittance, and a sheet resistance of the AgNRs layer is presented in Table 1. The sheet resistance value is inversely proportional to the number of dipping cycles as shown in Figure 2(d). This condition indicates that the sheet resistance of the AgNRs layer increases with the number of layers. Furthermore, the shape and morphology of the AgNRs solution and the AgNRs layer were observed using SEM at a voltage of $10 \mathrm{kV}$ as shown in Figure 5.
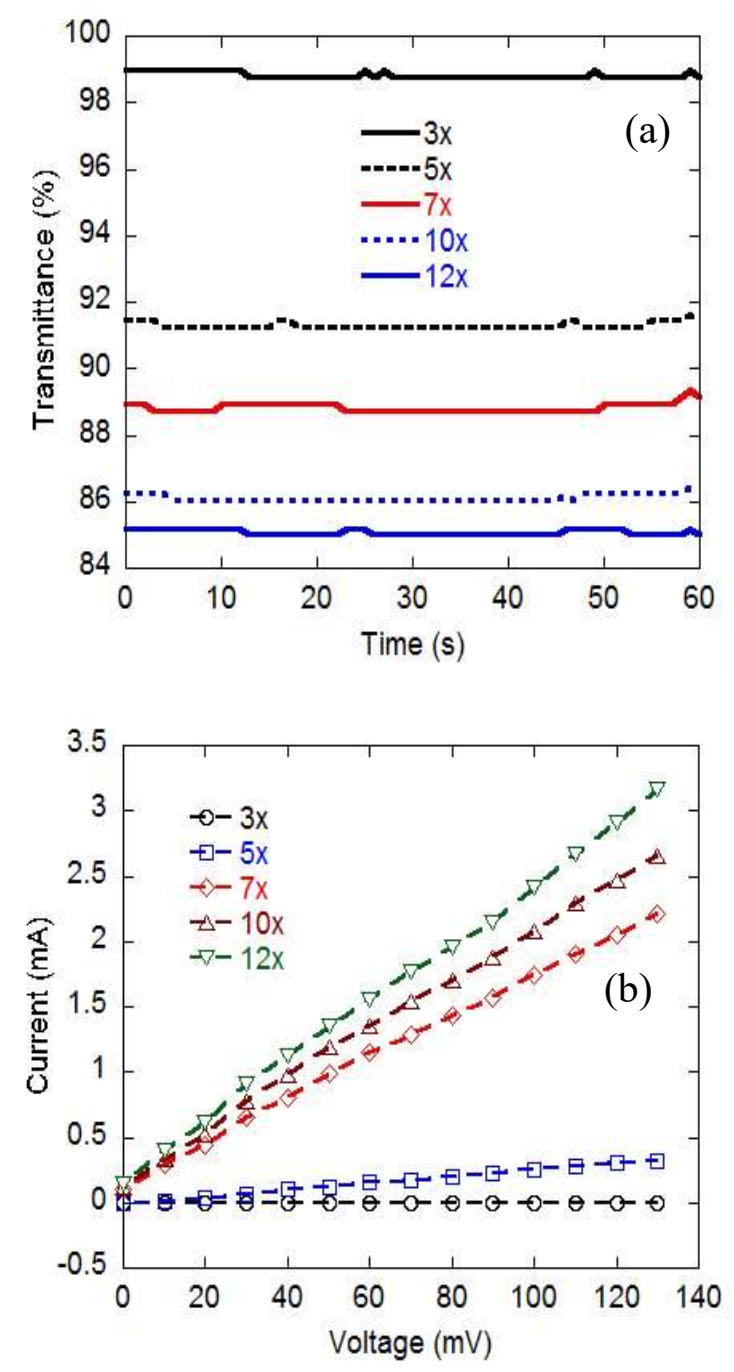

Figure 4. (a)Optical Transmittance of AgNRs Layer Using DAS MA-16 and (b) I-V Meter of AgNRs Layer.

Table 1. Optical Transmittance and Sheet Resistance of AgNRs Layer.

\begin{tabular}{ccc}
\hline $\begin{array}{c}\text { Number of } \\
\text { dipping } \\
\text { cycles }\end{array}$ & $\begin{array}{c}\text { Optical } \\
\text { transmittance } \\
(\boldsymbol{\%})\end{array}$ & $\begin{array}{c}\text { Sheet } \\
\text { resistance }(\boldsymbol{\Omega} \\
\left.\mathbf{s q}^{-1}\right)\end{array}$ \\
\hline 3 & $95 \pm 3$ & $1500 \pm 100$ \\
5 & $93 \pm 3$ & $720 \pm 50$ \\
7 & $90 \pm 3$ & $175 \pm 30$ \\
10 & $85 \pm 3$ & $90 \pm 20$ \\
12 & $80 \pm 3$ & $30 \pm 5$ \\
\hline
\end{tabular}


Figure 5(a) is an SEM image of AgNRs solution which was synthesized using a polyol method. Silver nanorods obtained were with diameter and length average about of $800 \mu \mathrm{m}$ and 10 to $20 \mathrm{~nm}$, respectively. Figure 5(a) also shows that AgNRs produced uniform and homogeneous without agglomerated with the crystal structure of face-centered cubic (fcc) [23].
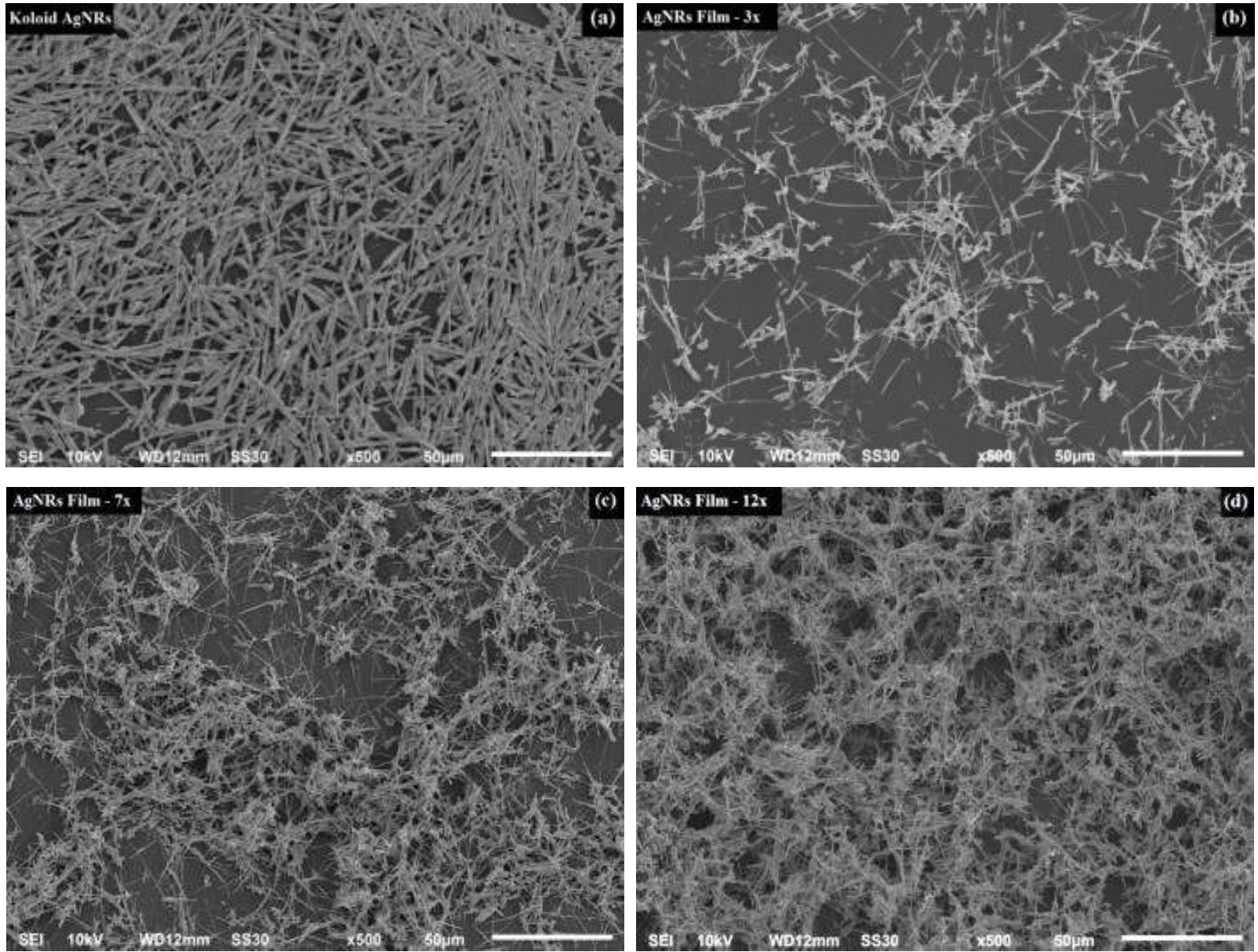

Figure 5. SEM Images of (a) Silver Nanorods Suspension and (b-d) Silver Nanorods Layer.

SEM images for the AgNRs layer with the variation of dipping cyclesare shown in Figure 5(b-c). Figure 5(b) is an SEM image of the AgNRs layer with five times of dipping cycles. According to the SEM image shows that the number of AgNRs deposited onto a glass substrate is slight. This causes the value of the optical transmittance of the AgNRs layer is high. In this condition, the sheet resistance is high, and the electrical conductivity is low. The sheets resistance of the AgNRs layer is very well when the coating process performed for seven times. The number of AgNRs attached to the substrate will increase with the number of dipping cycles. Figures 5(c-d) indicate that repetition of dipping cycles process does not damage or eliminate AgNRs which have first been deposited on the substrate. With the sheet resistance of $\sim 30 \quad \Omega \quad \mathrm{sq}^{-1}$ and optical transmittance above of $80 \%$, the AgNRs layer can be used as the alternative of a conductive and transparent electrode for various applications.

\section{IV.CONCLUSION}

The synthesis silver nanorods were carried out using ethylene glycol, polyvinyl alcohol, and sodium chloride by controlling the oil bath temperature. The silver nanorods 
Jurnal Penelitian Fisika dan Aplikasinya (JPFA), 2019; 9(1): 1-9

produced in high yield, uniform, and homogeneous without agglomeration occur during the synthesis process. SEM images show the size of the diameter and length of AgNRs of $800 \mathrm{~nm}$ and $15 \mu \mathrm{m}$, respectively. Optical transmittance of AgNRs layer obtained range from 80 to $90 \%$ with the sheet resistance under of $200 \Omega \mathrm{sq}^{-1}$ onto a glass substrate $10 \times 25 \mathrm{~mm}^{2}$. A number of dipping cycles in the dip-coating method are very important for controlling the thickness, optical transmittance, and sheet resistance of the AgNRs layer. The optical transmittance and sheet resistance are linear to the number of dipping cycles. The AgNRs layer is potential as the alternative transparent electrodes of organic solar cells.

\section{ACKNOWLEDGMENT}

This work supported by a research grant of "Post Graduate Doctoral, with the contract number 392/UN26.21/PN/2018”, by Ministry of Research, Technology and Higher Education (RISTEKDIKTI) of the Republic of Indonesia. Acknowledgments are also extended to Institutes for Research and Community Service, Universitas Lampung.

\section{REFERENCES}

[1] Hecht DS, Hu L, and Irvin G. Emerging Transparent Electrodes Based on Thin Films of Carbon Nanotubes, Graphene, and Metallic Nanostructures. Advanced Materials. 2011; 23(13): 1482-1513. DOI: https://doi.org/10.1002/adma.201003188.

[2] Kim H, Gilmore CM, Piqué A, Horwitz JS, Mattoussi H, Murata H, Kafafi ZH, and Chrisey DB. Electrical, Optical, and Structural Properties of Indium-Tin-Oxide Thin Films for Organic Light-Emitting Devices. Journal of Applied Physics. 1999; 86(11): 6451-6461. DOI: https://doi.org/10.1063/1.371708.
[3] Kim YS, Chang MH, Lee EJ, Ihm DW, and Kim JY. Improved Electrical Conductivity of PEDOT-Based Electrode Films Hybridized with Silver Nanowires. Synthetic Metals. 2014; 195: 69-74. DOI:

https://doi.org/10.1016/j.synthmet.2014.04.0 32.

[4] Kim D, Zhu L, Jeong DJ, Chun K, Bang YY, Kim SR, Kim JH, and Oh SK. Transparent Flexible Heater Based on Hybrid of Carbon Nanotubes and Silver Nanowires. Carbon. 2013; 63: 530-536. DOI:

https://doi.org/10.1016/j.carbon.2013.07.030.

[5] Hecht DS, Thomas D, Hu L, Ladous C, Lam T, Park Y, Irvin G, and Drzaic P. CarbonNanotube Film on Plastic as Transparent Electrode for Resistive Touch Screens. Journal of the Society for Information Display. 2009; 17(11): 941-946. DOI: https://doi.org/10.1889/JSID17.11.941.

[6] Teppei A, Jinting J, Masaya N, Hirotaka K, Shijo N, Tohru SKS, and Katsuaki S. Low Haze Transparent Electrodes and Highly Conducting Air Dried Films with Ultra-Long Silver Nanowires Synthesized by One-Step Polyol Method. Nano Research. 2014; 7(2): 236-245. DOI:

https://doi.org/10.1007/s12274-013-0391-x.

[7] Azuma K, Sakajiri K, Matsumoto H, Kang S, Watanabe J, and Tokita MF. Facile Fabrication of Transparent and Conductive Nanowire Networks by Wet Chemical Etching With an Electrospun Nanofiber Mask Template. Materials Letter. 2014; 115 : 187-189. DOI:

https://doi.org/10.1016/j.matlet.2013.10.054.

[8] Dinh DA, Hui KN, Hui KS, Kumar P, and Singh J. Silver Nanowires: A Promising Transparent Conducting Electrode Material for Optoelectronic and Electronic Applications. Reviews in Advanced Sciences and Engineering. 2013; 2(4): 1-22. DOI: http://dx.doi.org/10.1166/rase.2013.1048. 
Jurnal Penelitian Fisika dan Aplikasinya (JPFA), 2019; 9(1): 1-9

[9] Feliciano $\mathrm{J}$ and Martínez-Iñesta $\mathrm{MM}$. Synthesis and Characterization of $\mathrm{Pd}, \mathrm{Cu}$, and Ag Nanowires in Anodic Alumina Membranes Using Solid State Reduction. Materials Letter. 2012; 82(3): 211-213. DOI: https://doi.org/10.1016/j.matlet.2012.05.115.

[10] Tang X, Tsuji M, Jiang P, Nishio M, Jang SM, and Yoon SH. Rapid and High-Yield Synthesis of Silver Nanowires Using AirAssisted Polyol Method with Chloride Ions. Colloids and Surfaces A: Physicochemical and Engineering Aspects. 2009; 338(1-3): 33-39. DOI:

https://doi.org/10.1016/j.colsurfa.2008.12.0 29.

[11] Rajesh D and Sunandana CS. Controlled Formation of Porous Silver Nanowires. Chemical Physics Letters. 2014; 610-611: 363-368. DOI:

https://doi.org/10.1016/j.cplett.2014.07.056.

[12] Amirjani A, Marashi P, and Fatmehsari DH. Effect of $\mathrm{AgNO}_{3}$ Addition Rate on Aspect Ratio of CuCl2-Mediated Synthesized Silver Nanowires Using Response Surface Methodology. Colloids and Surfaces A: Physicochemical and Engineering Aspects. 2014; 444: 33-39. DOI:

https://doi.org/10.1016/j.colsurfa.2013.12.03.

[13] Mi HY, Li Z, Turng LS, Sun Y, and Gong S. Silver Nanowire/Thermoplastic Polyurethane Elastomer Nanocomposites: Thermal, Mechanical, and Dielectric Properties. Materials Design. 2014; 56: 398404. DOI:

https://doi.org/10.1016/j.matdes.2013.11.029.

[14] Tokuno T, Nogi M, Jiu J, and Suganuma K. Hybrid Transparent Electrodes of Silver Nanowires and Carbon Nanotubes: A LowTemperature Solution Process. Nanoscale Research Letters. 2012; 7(1): 281. DOI: https://doi.org/10.1186/1556-276X-7-281.

[15] Naito K, Yoshinaga N, Tsutsumi E, and Akasaka Y. Transparent Conducting Film Composed of Graphene and Silver Nanowire
Stacked Layers. Synthetic Metals. 2013; 175: 42-46. DOI:

https://doi.org/10.1016/j.synthmet.2013.04.02 $\underline{5}$.

[16] Margulis GY, Christoforo MG, Lam D, Beiley ZM, Bowring CDB, Salleo A, and McGehee MD. Spray Deposition of Silver Nanowire Electrodes for Semitransparent Solid-State Dye-Sensitized Solar Cells. Advanced Energy Materials. 2013; 3(12): 1657-1663. DOI:

https://doi.org/10.1002/aenm.201300660.

[17] Sachse C, Müller-Meskamp L, Bormann L, Kim YH, Lehnert F, Philipp A, Beyer B, and Leo K. Transparent, Dip-Coated Silver Nanowire Electrodes for Small Molecule Organic Solar Cells. Organic Electronics: Physics, Materials, Applications. 2013; 14(1): 143-148. DOI:

https://doi.org/10.1016/j.orgel.2012.09.032.

[18] Wu LYL, Kerk WT, and Wong CC. Transparent Conductive Fi Lm by Large Area Roll-To-Roll Processing. Thin Solid Films. 2013; 544: 427-432. DOI:

https://doi.org/10.1016/j.tsf.2013.02.087.

[19] Lim JW, Cho DY, Jihoon-Kim, Na SI, and Kim HK. Simple Brush-Painting of Flexible and Transparent Ag Nanowire Network Electrodes as an Alternative ITO Anode for Cost-Efficient Flexible Organic Solar Cells. Solar Energy Materials and Solar Cells. 2012; 107: 348-354. DOI:

https://doi.org/10.1016/j.solmat.2012.07.012.

[20] Liu CH and Yu X. Silver Nanowire-Based Transparent, Flexible, and Conductive Thin Film. Nanoscale Research Letters. 2011; 6(1): 75. DOI: https://doi.org/10.1186/1556-276X-6-75.

[21] Junaidi, Triyana K, Sosiati H, Suharyadi E, and Harsoyo. Effect of Temperature on Silver Nanorods Synthesized by Polyol Method. Advanced Materials Research. 2015; 1123: 256-259. DOI:

https://doi.org/10.4028/www.scientific.net/ AMR.1123.256. 
Jurnal Penelitian Fisika dan Aplikasinya (JPFA), 2019; 9(1): 1-9

[22] Junaidi, Triyana K, Suharyadi E, Harsojo, and $\mathrm{Wu}$ LYL. The Roles of Polyvinyl Alcohol (PVA) as the Capping Agent on the Polyol Method for Synthesizing Silver Nanowires. Journal of Nano Research. 2017; 49: 174-180. DOI:

https://doi.org/10.4028/www.scientific.net/J NanoR.49.174.

[23] Nghia NV, Truong NNK, Thong NM, and Hung NP. Synthesis of Nanowire-Shaped Silver by Polyol Process of Sodium Chloride. International Journal of Materials and Chemistry. 2012; 2(2): 75-78. DOI: https://doi.org/10.5923/j.ijmc.20120202.06.

[24] Johan MR, Azri N, Aznan NAK, Yee ST, Ho IH, Ooi SW, Singho ND, and Aplop F. Synthesis and Growth Mechanism of Silver Nanowires Through Different Mediated Agents $\left(\mathrm{CuCl}_{2}\right.$ and $\left.\mathrm{NaCl}\right)$ Polyol Process. Journal of Nanomaterials. 2014; 105454.

DOI: http://dx.doi.org/10.1155/2014/105454.

[25] Yan Y, Chen K, Li H, Hong W, Hu X, and $\mathrm{Xu}$ Z. Capping Effect of Reducing Agents and Surfactants in Synthesizing Silver Nanoplates. Transactions of Nonferrous
Metals Society of China. 2014; 24(11): $3732-$ 3738. DOI:

https://doi.org/10.1016/S10036326(14)63522-6.

[26] Hu L, Kim HS, Lee JY, Peumans P, and Cui Y. Scalable Coating and Properties of Transparent, Flexible, Silver Nanowire Electrodes. ACS Nano. 2010; 4(5): 29552963. DOI:

https://doi.org/10.1021/nn1005232.

[27] Junaidi, Aba L, and Triyana K. An Automatic Data Acquisition System for Optical Characterization of PEDOT : PSSbased Gas Sensor. AIP Conference Proceeding. 2015; 1656(1): 040001. DOI: https://doi.org/10.1063/1.4917108.

[28] Junaidi, Triyana K, Harsojo, and Suharyadi E. 2017. High-Performance Silver Nanowire Film on Flexible Substrate Prepared by Meyer-rod Coating. IOP Conf. Series: Materials Science and Engineering. 2017; 202: 012055. DOI:

http://dx.doi.org/10.1088/1757$\underline{899 X / 202 / 1 / 012055}$. 